UDC 616-02: 613.63: 669]-084

DOI: $10.21668 /$ health.risk/2020.2.08.eng

\title{
CORPORATE PROGRAMS FOR PREVENTING HEALTH DISORDERS AMONG WORKERS EMPLOYED AT ADVERSE PRODUCTIONS AS A TOOL FOR OCCUPATIONAL RISK MANAGEMENT
}

\author{
O.Yu. Ustinova ${ }^{1,2}$, N.V. Zaitseva ${ }^{1}$, E.M. Vlasova ${ }^{1}$, V.G. Kostarev ${ }^{3}$ \\ ${ }^{1}$ Federal Scientific Center for Medical and Preventive Health Risk Management Technologies, 82 Monastyrskaya Str., \\ Perm, 614045, Russian Federation \\ ${ }^{2}$ Perm State University, 15 Bukireva Str., Perm, 614990, Russian Federation \\ ${ }^{3}$ Federal Service for Surveillance over Consumer Rights protection and Human Well-being, Perm regional office, \\ 50 Kuibysheva Str., Perm, 614016, Russian Federation
}

Given the existing social and economic conditions, a true priority in activities performed by specialists in occupational medicine and labor protection is to preserve workers health and to prolong periods of their working capability. Experience in cooperating with employers who were interested in preserving their highly qualified personnel revealed that implementation of corporate prevention programs at an enterprise allowed reducing work-related and occupational health risks for workers.

Our research goal was to assess efficiency of a corporate prevention program bearing in mind managing occupational and work-related risks.

Data and methods. Our test group included 221 male workers employed at chemical productions in Perm (aged 55-40, average working experience amounted to $19.2 \pm 7.8$ years): our reference group was made up of 79 office workers employed at the same enterprises (aged 55-39, average working experience amounted to $21.2 \pm 7.6$ ). The research involved analyzing result of specific assessment of working conditions; medical documentation analysis; clinical, laboratory, and instrumental research; mathematical processing of all obtained data with creating predictive evolution models of occupational risks.

Results. A priori occupational risks for workers from the test group were high (intolerable) and average (significant); risks for workers from the reference group were small and negligible. An assessment of a cause-and-affect relation between work and health disorders revealed that $A H(E F=66 \%)$ and respiratory organs diseases $(E F=51 \%)$ were to a great extent work-related. Basic pathogenetic mechanisms of circulatory system diseases and respiratory organs diseases were determined as per research results; they were syndromes of endothelial dysfunction, sub-clinic inflammation, and oxidative stress; given that, we developed a corporate prevention program aimed at preventing health disorders among workers.

Results of the program implementation revealed that there was an authentic decrease in number of workers who had high blood pressure at the moment of a periodical medical examination (38\% prior to the program implementation and $11 \%$ after it had been implemented, $p<0.05)$; there was 1.8 times decrease in number of workers who were not admitted to perform specific work tasks due to detected circulatory system diseases (14 workers prior the program implementation and 8 workers after it had been implemented, $p<0.05)$ and practically 3 times decrease in number of workers who were not admitted due to respiratory organs diseases (32 workers prior the program implementation and 11 workers after it had been implemented, $p<0.05)$; there was also a decrease in number of workers who applied for medical aid.

Key words: occupational risk, risk management, corporate prevention programs, prevention of health disorders, assessment of working conditions, circulatory system diseases, respiratory organs diseases.

Given contemporary socioeconomic conditions, a top priority in activities performed by experts in labor protection and occupational medicine is to preserve employable population's health and prolong employment as much as it's only possible. A decrease in probability of untimely deaths caused by non-communicable diseases leads to labor potential preservation [1]. Health protection and safe working conditions are guaranteed by law ${ }^{1}$; they may as well be

(c) Ustinova O.Yu., Zaitseva N.V., Vlasova E.M., Kostarev V.G., 2020

Olga Yu. Ustinova - Doctor of Medical Sciences, Associate Professor, Head of Human Ecology and Life Safety Department (e-mail: ustinova@fcrisk.ru; tel.: +7 (342) 236-32-64; ORCID: http://orcid.org/0000-0002-9916-5491).

Nina V. Zaitseva - Academician of the Russian Academy of Sciences, Doctor of Medical Sciences, Professor, Scientific Director (e-mail: znv@fcrisk.ru; tel.: +7 (342) 237-25-34; ORCID: https://orcid.org/0000-0003-2356-1145).

Elena M. Vlasova - Candidate of Medical Sciences, Head of Prevention Center (e-mail: vlasovaem@fcrisk.ru; tel.: +7 (342) 236-87-60; ORCID: http://orcid.org/0000-0003-3344-3361).

Vitalii G. Kostarev - Candidate of Medical Sciences, Chief State Sanitary inspector in Perm region, Head of Rospotrebnadzor office in Perm region (e-mail: urpn@59.rospotrebnadzor.ru; tel.: +7 (342) 239-35-63).

${ }^{1}$ The RF Constitution adopted on December 12, 1993 by the nation-wide voting (with amendments made by the RF Laws on Amendments to the RF Constitution issued on December 30, 2008 No. 6-FKZ, December 30, 2008 No. 7-FKZ, February 05, 2014 No. 2-FKZ, July 21, 2014 No. 11-FKZ). KonsultantPlus. Available at: http://www.consultant.ru/ document/cons_doc_LAW_28399/(20.05.2020) (in Russian). 
fixed by a collective labor contract ${ }^{2}$. Any labor potentially causes damage to health [2-4]. Chemical production usually involves complex negative effects produced by occupational factors on workers; these factors include in-plant noise, vibration, microclimate, chemicals in working area air (WAA) that are typical for a specific production and industrial dusts in concentration higher than maximum permissible ones (MPC). There are also adverse working conditions such as labor hardness and intensity and occupational stress. Exposure to chemicals used in technological processes is intermittent in its essence during a work shift [5]. Long-term permanent combined exposure to adverse chemical and physical factors together with adverse working conditions leads to a decrease in body functional reserves and disorders in biochemical processes (intensified gluconeogenesis, atherogenesis, and free radical damage to cell membranes) consequently resulting in pathological changes in organs and systems (most frequently, cardiovascular disorders) $[5,6]$. Clear stages in development of pathological changes in a body is registered depending on target organs or systems, mechanism of action, and intensity of effects produced by an occupational factor [3]. Exposure to chemical factors most frequently leads to primary non-specific changes in circulatory and respiratory systems (arterial hypertension $(\mathrm{AH})$, atherosclerosis with damage to peripheral and extracranial arteries, as well as multi-focal atherosclerosis and airway conductance disorders) $[6,7]$. Occupational risks could be ranked from negligible to high depending on working conditions. Exposure to industrial aerosols authentically increases risks of somatic pathology in the respiratory organs. Diagnosing subclinical disorders during a periodical medical examination (PME), including those performed on workers with long working experience, will allow a delay in diseases occurrence and will ensure working ability preservation $\lceil 7,8]$.

Occupational and work-related risks assessment and management is an integral component in labor protection that includes preserving workers' life and health during their occupational activities (determining correlations between health disorders and work; developing procedures that allow estimating occupational risks) [9-11].

In practice, PMEs are the basic preventive activity that should be performed by an employer; they are regulated by the Order No. $302 n^{3}$ and aimed at detecting clinical forms of diseases that are medical contraindications to any further work. This conventional approach doesn't have either medicalpreventive components or any elements of occupational risk management.

Our experience in interacting with employers who take genuine interest in preserving their highly qualified personnel revealed that when corporate prevention programs were implemented at an enterprise taking into account risks of occupational diseases, it allowed minimizing health risks for workers and preserving their working abilities [7].

Our research goal was to assess efficiency of a corporate prevention program in view of occupational risk management.

Data and methods. To achieve the fixed goals, we made up a test group that included 221 male workers employed at chemical productions operating in Perm region (aged 55-40, average working experience was $19.2 \pm 7.8$ years), and a reference group that included 79 administrative workers from the same enterprises (aged 55-39, average working experience was $21.2 \pm 7.6)$. Workers from the test group mostly had the following occupations: a chlorination operator, an operator dealing with melted salts electrolysis, a founder, a non-ferrous metals and alloys caster, and a baking worker. The reference group included specialists in labor protection and industrial safety, and engineers who were not exposed to adverse occupational factors at their workplaces. Both groups were comparable in terms of sex, social position, working experience duration, and age. To analyze contributions made by occupational factors into health disorders as working experience grew longer, we divided workers from both groups into sub-groups accor-

\footnotetext{
${ }^{2}$ The RF Labor Code issued on December 30, 2001 No. 197-FZ (last edited on August 02, 2019). KonsultantPlus. Available at: http://www.consultant.ru/document/cons_doc_LAW_34683/ (20.05.2020) (in Russian).

${ }^{3}$ On Approving the list of adverse and (or) hazardous occupational factors and work tasks performance of which requires preliminary and periodical medical examinations (check-ups) and the procedure for accomplishing preliminary and periodical medical examinations (check-ups) of workers employed at workplaces with adverse and (or) hazardous working conditions. The Order by the RF Public Healthcare Ministry issued on April 12, 2011 No. 302n (last edited on May 18, 2020). KonsultantPlus. Available at: http://www.consultant.ru/document/cons_doc_LAW_120902/ (20.05.2020) (in Russian).
} 
ding to their working experience: $0-5$ years; $5.1-10$ years; $10.1-15$ years; 15.1 years and longer.

Our research involved analyzing results obtained via special assessment of working conditions (SAWC) performed at examined workers' workplaces; analyzing medical documentation and ultimate PME reports; clinical examinations by medical experts with assessing functional state of the circulatory and respiratory systems; laboratory and instrumental examinations; mathematical processing of the obtained data together with building up prognostic evolution models for occupational risks [12].

We also performed sociologic research on prevalence of non-occupational risk factors that exerted their influence on circulatory system diseases (CSD) and respiratory organs diseases (ROD); it was done via handing out questionnaires to respondents who were selected via targeted sampling [13].

To assess functional activity of vessel endothelium, we tested flow-dependent (endothelium-dependent) vasodilatation of the brachial artery with «Vivid q» (GE Vingmed U1trasound AS, Norway) u-sound scanner with the linear device 4-13 MHz (D.S. Celermajer).

Morphological structure of extracranial sections in the brachiocephalic arteries (BCA) was assessed with «Vivid q» (GE Vingmed Ultrasound AS, Norway) u-sound scanner with the linear device 4-13 MHz. We assessed Intima-media Thickness (IMT).

Heart rhythm and balance between sections in the vegetative nervous system (VNS) were assessed as per the conventional procedure (R.M. Baevskiy, 1979; D. Zhemaytite, 1989) with «Poly-Spectr-8/EX» software package (Neirosoft, Russia).

External breath was analyzed via spirography performed with SP-20 device (Schiller AG, Switzerland).

Laboratory examinations included tests performed with unified hematologic, biochemical, and ELISA techniques that allowed assessing functional state of target organs. Laboratory diagnostics was performed with automatic analyzers (hematologic AcT5diff AL device, the USA, and Backman, France; biochemical Konelab
20 device, ThermoFisher, Finland; and «Infinite F50 Teca» device for ELISA test, Austria).

Risks were assessed in conformity with Guide R 2.2.1766- $03^{4}$. A relation between a health disorder and working conditions was established basing on relative risk (RR), confidence interval (CI), and etiological fraction of responses caused by exposure to occupational risk factors (EF); to do that, we used an electronic calculating device [9].

We processed all the data statistically with variation statistics techniques. Statistic hypotheses were tested against model parameters with Student's t-test and chi-square $\left(\chi^{2}\right)$. Should distribution be normal and Student's ttest applied, the data were given as simple mean (S) and standard deviation (SD); in case distribution was not normal, the data were given as median $(\mathrm{Me})$ and interquartile range (the $25^{\text {th }}$ and $75^{\text {th }}$ percentiles). Significance was taken as $p=0.05(p<0.05)$. All the obtained data were processed with SPSS 16.0, Stata/SE 12.1 software packages for Windows, and a program module made as MS Excel macro. We also performed situation modeling [14-16].

The research was performed within the Scientific Research Program adopted by the Federal scientific Center for Medical and Preventive Health Risk Management Technologies for 2018 in conformity with the standards fixed in Helsinki Declaration (last edited in 2008) and ICHGCP rules as well as in conformity with the RF National Standard GOST R 52379-2005 «Good Clinical Practice» (ICH E6 GCP). The research program was approved on the local ethical Committee meeting (meeting report No. 33 dated February 12, 2018).

Results and discussion. Working conditions at workplaces of workers with basic occupations existing at chemical productions involved combined exposure to chemical factors (chlorine and its compounds; sulfur and its compounds), physical factors (noise, vibration, and microclimate), and labor hardness. According to SAWC, working conditions were assessed as «hazardous» at $100 \%$ workplaces of workers from the test group; they were «acceptable» for workers from the reference group (Table 1).

\footnotetext{
${ }^{4}$ Guide on assessing health risks for workers. Organizational and methodical grounds, principles, and assessment criteria. 2.2. Occupational hygiene. KODEKS: the electronic fund for legal and reference documentation. Available at: http://docs.cntd.ru/document/901902053 (20.05.2020) (in Russian).
} 
Table 1

Workplaces of workers form the test and reference groups ranked as per working conditions according to special assessment of working conditions, $\%$

\begin{tabular}{|l|c|c|c|c|c|}
\hline \multirow{3}{*}{ Group } & \multicolumn{5}{|c|}{$\begin{array}{l}\text { Specific weight of workplaces } \\
\text { with different working condi- } \\
\text { tions categories }\end{array}$} \\
\cline { 2 - 6 } & 1 and 2 & 3.1. & 3.2. & 3.3. & 3.4. \\
\hline Test group & 0 & 30 & 55 & 15 & 0 \\
\hline Reference group & 100 & 0 & 0 & 0 & 0 \\
\hline
\end{tabular}

Table 2

Occupational risks for workers with most common occupations existing at chemical productions ( $\mathrm{G}$ 2.2.1766-03)

\begin{tabular}{|c|c|c|c|}
\hline \multicolumn{2}{|c|}{ Test group } & \multicolumn{2}{c|}{ Reference group } \\
\hline $\begin{array}{c}\text { Workplace } \\
\text { operator }\end{array}$ & $\begin{array}{c}\text { Occupa- } \\
\text { tional risk }\end{array}$ & Workplace & $\begin{array}{c}\text { Occupa- } \\
\text { tional risk }\end{array}$ \\
\hline $\begin{array}{c}\text { helted salts } \\
\text { (intolerable) }\end{array}$ & Foreman & $\begin{array}{c}\text { small } \\
\text { (moderate) }\end{array}$ \\
$\begin{array}{c}\text { average } \\
\text { operator } \\
\text { (substantial) }\end{array}$ & $\begin{array}{c}\text { Senior } \\
\text { foreman }\end{array}$ & $\begin{array}{c}\text { small } \\
\text { (moderate) }\end{array}$ \\
\hline $\begin{array}{c}\text { Non-ferrous } \\
\text { metals and } \\
\text { alloys caster }\end{array}$ & $\begin{array}{c}\text { average } \\
\text { (substantial) }\end{array}$ & $\begin{array}{c}\text { Team } \\
\text { supervisor }\end{array}$ & negligible \\
\hline Founder & $\begin{array}{c}\text { average } \\
\text { (substantial) }\end{array}$ & $\begin{array}{c}\text { Assistant } \\
\text { to workshop } \\
\text { head }\end{array}$ & negligible \\
\hline $\begin{array}{c}\text { Baking } \\
\text { worker }\end{array}$ & $\begin{array}{c}\text { average } \\
\text { (substantial) }\end{array}$ & $\begin{array}{c}\text { Workshop } \\
\text { head }\end{array}$ & negligible \\
\hline
\end{tabular}

Workers from the test group ran a priori high (intolerable) and average (substantial) occupational risks; workers from the reference group ran small and negligible occupational risks (Table 2).

Having analyzed prevalence of behavioral risk factors, we revealed that there were no statistically authentic differences between two groups $(p>0.05)$. In particular, a share of smokers amounted to $31 \%$ and $27 \%$ in the test and the reference group accordingly $(p>0.05)$. Workers from the test group had been smoking on average for 20 years (15 cigarettes a day on average), and workers from the reference group, for 18 years (13 cigarettes a day, $p>0.05)$. We analyzed attitudes towards drinking alcohol and also didn't reveal any authentic differences. We established that most examined workers drank alcohol 2 times per month (86\% workers from the test group, $77 \%$ workers from the reference group, $p>0.05)$. Choice on spirits was influenced by education. Workers with high education preferred low alcohol spirits (wine) in $62.2 \%$ cases, V Cramers $=0.464$, $p<0.05$. People with primary and secondary education chose fortified wines or strong spirits, $\mathrm{V}$ Cramers $=0.469, p<0.05$. We revealed a weak relation $(r=0.2, p<0.05)$ between a worker's age and beer consumption; workers younger than 30 drank beer once a week or more often in a quantity exceeding 1 liter (43.7\% in the test group and $38.2 \%$ in the reference group; V Cramers $=0.469, p<0.05$ ).

Questioning performed among workers from the test group revealed either absence of complaints due to «a healthy worker syndrome» or them being non-specific; it made early diagnostics and prediction of working ability in the future more complicated. Clinical examinations allowed establishing that the leading place belonged to astheno-vegetative syndrome (increased fatigue, a decrease in working ability, often changes in moods, and sleep disorders); it was revealed practically in all examined workers form the test group.

Arterial hypertension $(\mathrm{AH})$ determined as per office arterial blood pressure (BP) was detected in $33 \%$ workers from the test group and in $18 \%$ workers from the reference one $\left(\chi^{2}=6.7, p=0.01, \mathrm{RR}=1.7 ; 95 \% \mathrm{CI}=1.1-3.1\right.$; $\mathrm{EF}=66 \%$ ). There was a growth in number of workers with the verified diagnosis depending on their working experience. Workers from the test group with their working experience exceeding 10 years tended to have AH 3.5 times more frequently $\left(\chi^{2}=4.3, p=0.03\right)$, and 2.7 times more frequently in case working experience exceeded 15 years $\left(\chi^{2}=6.7, p=0.01\right)$. The results are given in Table 3.

Table 3

Prevalence of arterial hypertension depending on working experience duration in the test and reference groups, $\%$

\begin{tabular}{|l|c|c|c|c|}
\hline \multirow{2}{*}{ Group } & \multicolumn{4}{|c|}{$\begin{array}{c}\text { Prevalence of arterial hypertension de- } \\
\text { pending on working experience duration }\end{array}$} \\
\cline { 2 - 5 } & $\begin{array}{c}0-5 \\
\text { years }\end{array}$ & $\begin{array}{c}5.1-10 \\
\text { years }\end{array}$ & $\begin{array}{c}10.1-15 \\
\text { years }\end{array}$ & $\begin{array}{c}\text { More than } \\
15 \text { years }\end{array}$ \\
\hline Test & 12.7 & 17.6 & 30.6 & 59.6 \\
\hline Reference & 4.0 & 5.0 & 9.0 & 22.3 \\
\hline$p^{*}$ & $p>0.05$ & $p>0.05$ & $p<\mathbf{0 . 0 5}$ & $p<\mathbf{0 . 0 5}$ \\
\hline
\end{tabular}

$\mathrm{N}$ o te : ${ }^{*} p$ means validity of discrepancies between the test and reference groups. 
Respiratory organs diseases (ROD) with obstructive disorders in the lower respiratory tracts more frequently occurred in workers from the test group as the parameter was 3 times higher than in the reference group $\left(\chi^{2}=17.6\right.$, $p<0.001, \mathrm{RR}=3.2,95 \% \mathrm{CI}=1.7-5.8$, $\mathrm{EF}=51 \%$ ). $19.1 \%$ workers with their working experience being 15 years or longer had chronic obstructive lungs disease; there were only $5 \%$ workers with the same disease in the reference group $(p<0.05)$. Pathology in the respiratory organs occurs in workers employed at chemical productions with certain peculiarities in the process; one of them is a long latent period in the disease development and external breath remaining within its conditional physiological standards due to functional reserves.

According to data taken from literature, occupational factors can act as triggers and induce pathogenetic mechanisms of non-communicable diseases occurrence and development. Adverse occupational factors (physical, chemical, and psychophysiological ones) cause imbalance between oxidant and anti-oxidant systems [17-20].

We assessed functional activity of the brachial artery endothelium with endotheliumdependent vasodilatation test; the assessment revealed that there was a pathologic reaction in $85.5 \%$ workers from the test group whereas a similar one was detected only in $3.7 \%$ workers from the reference group $\left(\chi^{2}=168.6\right.$, $p<0.001, \mathrm{RR}=22.5 ; 95 \% \mathrm{CI}=7.4-68.4$; $\mathrm{EF}=85 \%$ ). A growth in the brachial artery diameter after reocclusion amounted to $5.22 \pm 1.34$ in workers from the test group and to $13.53 \pm 1.08$ in their counterparts from the reference group $(p<0.001)$; average value of sensitivity coefficient was 5 times lower in workers from the test group than in those from the reference one $(0.053 \pm 0.024$ and $0.265 \pm 0.058, p<0.001)$. These results confirm the assumptions on a relation between disorders in endothelium functional activity and exposure to adverse occupational factors [21].

Mathematic modeling revealed that $\mathrm{AH}$ probability was predominantly related to in-plan noise $\left(F=1,621 ; R^{2}=0.95 ; p=0.001, r=0.3\right)$; ROD, to elevated concentrations of chlorine and its compounds in WAA $\left(F=296 ; R^{2}=0.79 ; p=\right.$ $0.003, r=0.3$ ); endothelial dysfunction, both to in-plant noise $\left(F=3,387 ; R^{2}=0.96 ; p<0.001\right.$; $r=0.6)$ and concentrations of chlorine and its compounds $\left(F=54 ; R^{2}=0.29 ; p<0.001\right)$.
Atherosclerosis signs, namely local increase in IMT, were registered practically in each third worker from the test group (29\% workers from the test group and $15 \%$ workers from the reference group, $\mathrm{p}=0.05, \mathrm{OR}=2.3$, $95 \% \mathrm{CI}=1.2-4.4 ; \mathrm{RR}=1.9,95 \% \mathrm{CI}=1.1-3.3)$. Ultrasound scanning performed on BCA revealed authentic discrepancies in IMT on extracranial level, $0.99 \pm 0.02 \mathrm{~mm}$ in workers from the test group against $0.77 \pm 0.05 \mathrm{~mm}$ in workers from the reference one $(p<0.001)$. And IMT growth rate amounted to $0.16 \mathrm{~mm}$ per year in workers from the test group with their working experience exceeding 10 years whereas the physiological standard for the parameter is not more than $0.0138 \mathrm{~mm}$ per year.

We analyzed results obtained via heart rhythm assessment and revealed grave disorders in compensatory mechanisms in $35 \%$ workers from the test group and only in $12 \%$ workers from the reference one. Those disorders were accompanied with pathologic stabilization of heart rhythm modulation with transition to neurohumoral regulation $\left(\chi^{2}=15.6\right.$, $p<0.01, \mathrm{RR}=3.9,95 \% \mathrm{CI}=1.5-2.3$; $\mathrm{EF}=46 \%)$. Our research revealed that $\mathrm{HF}$ strength (respiratory waves that reflect how active parasympathetic cardioinhibitory center in the medulla is) that characterizes activity of parasympathetic section in the regulation goes down greater than LF strength (that reflects how active sympathetic centers in the medulla are including cardioacceleratory and vasoconstrictive ones) in older workers from the test group. We observed a close relation between HF strength and RMSSD time parameters (a square root out of an average sum of squared differences between neighboring $\mathrm{NN}$ intervals) and pNN50 (a number of neighboring $\mathrm{NN}$ intervals pairs) and it mostly indicated that the parasympathetic system was quite active. Normally, weaker activity of parasympathetic influences and greater activity of sympathetic ones results in a decrease in the heart rhythm variability (HRV) structure only in people older than 50 . Average $\mathrm{HF}$ waves value in quiescence (HF1, \%) in workers from the test group was within its physiological standards but it was authentically lower than the same parameters in workers from the reference group $(33.2 \pm 3.4 \%$ in the test group, $27.9 \pm 3.1 \%$ in the reference one, $p=0.026$ ) and it indicated that central ergotropic and humoral-metabolic mechanisms 
were substantially active. Vagosympathetic interaction index (LF/HF1) was practically 2 times higher in workers from the test group than in those from the reference one $(1.9 \pm 0.5$ and $1.0 \pm 0.3$ accordingly, $p=0.008$ ). Having analyzed HRV time parameters, we revealed a decrease in SDNN1 in the test group $(50.5 \pm 5.9 \mu \mathrm{s}$ in the test group, $64.5 \pm 11.9 \mu \mathrm{s}$ in the reference group, $p=0.042$ ); RMSSD1 $(43.0 \pm 7.7 \mu \mathrm{s}, \quad 66.1 \pm 16.7 \mu \mathrm{s}$ accordingly, $p=0.013$ ) and it confirmed a decrease in HRV and greater tonus of the sympathetic nervous system against lower tonus of the parasympathetic nervous system in workers from the test group as compared with their counterparts from the reference one (Table 4).

Having analyzed all the obtained results, we established that there was dependence between a probable increase in vagosympathetic interaction index $(\mathrm{LF} / \mathrm{HF} 1)$ and a growth in inplant noise $\left(F=1,257 ; R^{2}=0.9 ; p<0.001\right.$, $r=0.6)$ as well as elevated concentrations of chlorine $\left(F=61 ; R^{2}=0.3 ; p<0.001, r=0.3\right)$ and hydrochloride $\left(F=136 ; R^{2}=0.5 ; p<0.001\right.$, $r=0.3)$ in working area air.

We analyzed spirography results and didn't reveal any deviations from physiological standards either in workers from the test group or those from the reference one. However, having analyzed spirography parameters in dynamics, we established that there was an annual decrease in fixed tidal volume per $1 \mathrm{sec}$ in $29 \%$ workers from the test group; it went down by $39.2 \pm 5.8 \mathrm{ml}$ per year while permissible decrease should not exceed $30 \mathrm{ml}$ per year. Annual decrease in fixed tidal volume per $1 \mathrm{sec}$ in workers from the reference group on average amounted to $31.5 \pm 3.1 \mathrm{ml}$ a year $(p<0.05)$ and it indicated that ROD developed subclinically in them.

We analyzed results obtained via laboratory examinations and revealed that there were certain deviations in parameters obtained for workers from the test group; those deviations reflected subclinical disorders in the circulatory and respiratory systems, namely already existing risks of cardiovascular disorders $(\mathrm{RR}=1.8$, $95 \% \mathrm{CI}=1.2-2.8 ; \mathrm{EF}=45 \%$ ) as well as secondary immunodeficiency signs and apparent adaptation reactions [21-23]. Workers from the test group had elevated concentrations of uric acid, up to $378[313 ; 420] \mu \mathrm{mol} / \mathrm{dm}^{3}$ (the parameter was $302[251 ; 358] \mu \mathrm{mol} / \mathrm{dm}^{3}$ in the reference group, $p<0.05)$. The said changes were revealed in workers with longer working experience, starting from 5.1-10 years (389 $(362 ; 421] \mu \mathrm{mol} / \mathrm{dm}^{3}, 296[239 ; 364]$ $\mu \mathrm{mol} / \mathrm{dm}^{3}$ in the reference group, $p<0.05$ ). There was a statistically significant increase in atherogenic fraction, or low density lipoproteins, in workers from the test group: $4.2[3.7 ; 5.5]$ $\mathrm{mmol} / \mathrm{dm}^{3},\left(3.2[2.8 ; 3.6] \mathrm{mmol} / \mathrm{dm}^{3}\right.$ in the reference group, $p<0.05)$. Concentration of supersensitive C-reactive protein was authentically higher in workers from the test group (6.7 [6.2; $7.2] \mathrm{mg} / \mathrm{dm}^{3}$ ) than the same parameter in the reference one, $5.0[4.5 ; 5.5] \mathrm{mg} / \mathrm{dm}^{3}(p<0.05)$, and VEGF concentrations in workers from the test group reached $345[242 ; 510] \mathrm{pg} / \mathrm{dm}^{3}$ $\left(179[90 ; 299] \mathrm{pg} / \mathrm{dm}^{3}\right.$ in the reference group,

Table 4

Time and spectral analysis of heart rhythm variability in quiescence in workers employed at chemical productions

\begin{tabular}{|l|c|c|c|c|}
\hline \multicolumn{1}{|c|}{ Parameter } & Physiological standard & Test group & Reference group & $P^{*}$ \\
\hline SDNN1, $\mu \mathrm{s}$ & $54.5-65.1$ & $50.5 \pm 5.8$ & $64.6 \pm 11.9$ & $<\mathbf{0 . 0 5}$ \\
\hline RMSSD1, $\mu \mathrm{s}$ & $36.3-48.5$ & $42.9 \pm 7.6$ & $66.2 \pm 16.6$ & $<\mathbf{0 . 0 5}$ \\
\hline TP1, $\mu \mathrm{s}^{2}$ & $1561-4754$ & $3021 \pm 673$ & $5223 \pm 2212$ & $>0.05$ \\
\hline VLF1, $\mu \mathrm{s}^{2}$ & $355.8-1175.1$ & $1138 \pm 222$ & $1574 \pm 507$ & $>0.05$ \\
\hline LF1, $\mathrm{ms}^{2}$ & $513.1-1425.5$ & $1040 \pm 280$ & $1438 \pm 697$ & $>0.05$ \\
\hline $\mathrm{HF} 1, \mu \mathrm{s}^{2}$ & $461.1-1618.0$ & $853 \pm 292$ & $2213 \pm 1190$ & $<\mathbf{0 . 0 5}$ \\
\hline LF/HF1 & $0.5-2.3$ & $1.9 \pm 0.5$ & $1.1 \pm 0.3$ & $<\mathbf{0 . 0 5}$ \\
\hline VLF1, \% & $17.51-39.79$ & $41.4 \pm 4.2$ & $37.2 \pm 4.3$ & $>0.05$ \\
\hline LF1, \% & $24.63-42.72$ & $33.2 \pm 3.4$ & $27.9 \pm 3.1$ & $<\mathbf{0 . 0 5}$ \\
\hline HF1, \% & $21.05-50.53$ & $25.6 \pm 4.1$ & $34.9 \pm 5.1$ & $<\mathbf{0 . 0 5}$ \\
\hline LF1 norm, n.u. & $41.2-60.0$ & $57.5 \pm 4.9$ & $46.3 \pm 5.4$ & $<\mathbf{0 . 0 5}$ \\
\hline HF1 norm, n.u. & $40.0-58.8$ & $42.4 \pm 4.7$ & $53.7 \pm 5.5$ & $<\mathbf{0 . 0 5}$ \\
\hline
\end{tabular}

$\mathrm{N}$ o t e : ${ }^{*} p$ means validity of discrepancies between the test and reference groups. 
$p<0.001)$. Comparative analysis of the parameter in sub-groups with different working experience duration revealed its maximum concentration in workers with their working experience being 15.1 years or longer $\left(471[332 ; 695] \mathrm{pg} / \mathrm{dm}^{3}\right.$ in the test group and $106[81 ; 259] \mathrm{pg} / \mathrm{dm}^{3}$ in the reference group, $p<0.001$ ). Homocysteine concentration amounted to $12.5[10.0 ; 14.4] \mu \mathrm{mol} / \mathrm{dm}^{3}$ in the test group and to $7.8[4.6 ; 12.2] \mu \mathrm{mol} / \mathrm{dm}^{3}$ in the reference one $(p<0.001)$; statistically significant discrepancies were revealed in workers with their working experience being 15.1 years and longer, $13.7[10.8 ; 14.9] \mu \mathrm{mol} / \mathrm{dm}^{3}$ in workers from the test group and $8.5[4.6 ; 13.6] \mu \mathrm{mol} / \mathrm{dm}^{3}$ in workers from the reference one $(p<0.05)$. It should be noted that hydrocortisone concentration in blood was higher in workers from the test group $\left(287[191 ; 487] \mathrm{nmol} / \mathrm{cm}^{3}\right)$ than the same parameter in workers from the reference one (204 $[178 ; 352] \mathrm{nmol} / \mathrm{cm}^{3}(p<0.05)$.

Having analyzed immunologic status and reactivity, we revealed that leucocytes concentration in blood was authentically higher in workers from the test group than in their counterparts from the reference one $\left(6.6[5.7 ; 8.5] \cdot 10^{9} / \mathrm{dm}^{3}\right.$ and 5.9 $[5.1 ; 7.2] \cdot 10^{9} / \mathrm{dm}^{3}$ accordingly, $\left.p<0.001\right)$. The most apparent inter-group discrepancy was detected for workers with their working experience being 15.1 years and longer $(6.7$ [5.6; 8.7]. $109 / \mathrm{dm}^{3}$ in workers from the test group, $5.5[4.7$; $7.2] \cdot 10^{9} / \mathrm{dm}^{3}$ in workers from the reference group, $p<0.05$ ). Phagocytic section disorders were also predominantly detected in workers from the test group (absolute phagocytosis in the test group was $2.11[1.54 ; 2.83] \cdot 10^{9} / \mathrm{dm}^{3}$; in the reference group, $\left.1.77[1.40 ; 2.23] \cdot 10^{9} / \mathrm{dm}^{3}, p<0.05\right)$; the same was true for humoral section in the immunity (IgA level amounted to $2.4[1.93 ; 2.83] \mathrm{g} / \mathrm{dm}^{3}$ in workers from the test group, and to 1.79 [1.40; $2.16] \mathrm{g} / \mathrm{dm}^{3}$ in workers from the reference one $(p<0.001)$ as well as for activation of cellular section in the immunity (CD16 + 56 + lymphocytes concentration amounted to 0.32 [0.27; $0.60] \cdot 10^{9} / 1$ in workers from the test group, and to $0.22[0.21 ; 0.25] \cdot 10^{9} / 1$ in workers from the reference one, $p<0.05$; CD3 + CD25 + concentration amounted to $0.35[0.24 ; 0.52] \cdot 10^{9} / 1$ in the test group, and to $0.14[0.10 ; 0.16] \cdot 10^{9} / 1$ in the reference one, $p<0.001$ ).

Research results allowed us to determine basic pathogenetic components in CSD and ROD development; they were endothelial dysfunction, subclinical inflammation, and anti- oxidant stress. Taking them into account, we developed a corporate program aimed at preventing health disorders among workers [7].

Our experience in interacting with enterprises revealed that such programs would be implemented more efficiently in case there was interaction with experts in labor protection. Hygienic activities allow reducing risks for workers' health.

Having built mathematical models for «exposure - working experience - response» dependence, we established a probability of workrelated ROD depending on level and duration of exposure to adverse occupational factors. Risk of ROD occurrence in workers employed at chemical productions, given the existing working conditions, will create 6 additional cases by the end of the $1^{\text {st }}$ working year; by the end of the $5^{\text {th }}$ year there will be 14 additional cases. As for workrelated $\mathrm{AH}$, by the end of the $1^{\text {st }}$ year there will be 8 additional cases; by the end of the $10^{\text {th }}$ year, 25 additional cases per year.

Situation modeling revealed that a decrease in chlorine concentration in working area air to its MPC can make for $42 \%$ lower individual ROD risks for workers with long working experience ( 5 years and longer) (from 14 to 6 cases per year).

Taking all the obtained results into account, we developed a corporate health preservation program with workers being distributed into several risk groups:

- the $1^{\text {st }}$ group included workers who didn't have any complaints, any clinical signs of ROD and/or CSD (satisfactory adaptation or resistance);

- the $2^{\text {nd }}$ group included workers who didn't have any complaints but still had certain functional disorders without any clinical symptoms (unsatisfactory adaptation);

- the $3^{\text {rd }}$ group included workers who had complaints and laboratory or functional signs of CSD and/or ROD (strain in adaptation);

- the $4^{\text {th }}$ group included workers with first diagnosed CSD or ROD who didn't have any contraindications to continuing their work (adaptation failure).

The risk groups were created as per PME results.

Corporate programs should involve interaction between labor protection and industrial safety services existing at an enterprise and medical organizations and centers for occupational pathologies treatment. 
Following PME results, an employer makes a decision whether it is advisable to develop and implement a corporate prevention program, then signs a contract with a scientific organization and entitles it to assess health risks for workers and to develop and implement relevant prevention programs.

Activities aimed at labor resources preservation that are employer's responsibility are: production modernization including creation of new workplaces with working conditions at them being «acceptable» for workers in preretirement age who have contraindications to working under hazardous conditions; providing workers with information on occupational risks; reducing influences exerted on workers by adverse factors (protection via time, lower doses, or distance); application of up-to-date individual protection means (active noise-absorbing earphones, semi-masks with replaceable filters, etc.); providing more qualitative PMEs.

According to workers' distribution into risks groups as per results obtained via a previous PME, workers from this contingent underwent more profound annual medical examination that included a greater range of procedures than it was stipulated by the Order No. 302n; after the examination workers were again distributed into risk groups in order to perform medical-preventive or medical-rehabilitating activities for those who needed them.

Primary prevention of circulatory system and respiratory organs diseases included the following: a worker was informed that CSD or ROD could probably occur and was provided with a short preventive consultation; motivation to preserve health was created; a worker was advised to control BP, body mass index, waist and thighs circumference, to give up smoking and to avoid passive smoking, to give up alcohol intake, to take regular and moderate physical exercises, to do sports and take annual walks outdoors, to keep healthy daily regime (to sleep for not less than 8 hours), to have balanced and rational nutrition, and to avoid stressful situations.

Medical activities included more profound medical examinations than it was regulated for a typical PME for workers who ran average and high occupational risks; such workers were also examined annually at a canter for occupational pathology.

Medical and rehabilitation activities recommended for workers from the $1^{\text {st }}$ risk groups included informing workers about occupational health risks; short preventive consultations; non-specific seasonal immune prophylaxis and motivation to preserve health.

Workers form the $2^{\text {nd }}$ risk group were provided with more profound preventive consultations; non-specific seasonal immune prophylaxis and anti-influenza vaccination; physical prevention including physiotherapy (aeroionization), acupuncture, head and neck massage, 10 sessions of therapeutic exercises, 14-day prevention treatment in a sanatorium.

Prevention programs for workers form the $3^{\text {rd }}$ risk group were added with vaccination with «Pnevmo 23» vaccine for workers who had often recurrent ROD; such workers were also provided with preventive medications including antioxidants, poly-vitamin and polymineral complexes taken for 14 days 2 times a year. In case of necessity they were provided with therapy to treat ROD and/or CSD. Physical prevention included medicinal phonophoresis and magnetotherapy, 10 sessions each, chest massage, and respiratory gymnastics, also 10 sessions each; antioxidant therapy, energy-saving mediations, and beta-carotene with minerals, all taken for 30 days.

Workers from the $4^{\text {th }}$ group were informed about occupational risks and forecasts for their future occupational activities; motivation to preserve health was created; they were provided with physical and medicinal prevention as well as treatment for their main disease (permanent hypotensive therapy and/or bronchodilators and mucolytic medications etc.); they also spent 21 days in a sanatorium and were provided with rehabilitation treatment there.

Medical-preventive and medical-rehabilitation activities include 4 stages. The first stage involves activities aimed at preventing ROD and CSD in workers from the $1^{\text {st }}$ group and they take place at an aid post belonging to an enterprise. The second stage involves activities aimed at preventing ROD and CSD in workers from the $2^{\text {nd }}$ risk group and those who often fall sick with long colds; it is implemented via organizing outpatient observations at an aid post of an enterprise together with a specialist in occupational pathology from a medical organization. The third stage is regular health improvement provided for workers with initial non-communicable ROD and with detected CSD predictors (the $3^{\text {rd }}$ risk group); such workers have medical examinations at a center 
for occupational pathology treatment where their occupational abilities are estimated. The fourth stage involves medical and rehabilitation activities provided for workers form the $4^{\text {th }}$ risk group annually at a center for occupational pathology treatment where their occupational abilities are estimated and a relation between a disease and occupational activities is determined.

Medical-preventive and medical-rehabilitation activities are aimed at life quality improvement, better tolerance to physical loads, working ability preservation, elimination or reduction in CSD and ROD symptoms, reduction in number of recurrent ROD or CSD gravity, and reduction in mortality.

One year after the corporate prevention program was implemented there was another medical examination. Its results revealed that a share of work-related circulatory system diseases went down $(\mathrm{EF}=66 \%$ prior to the program implementation; $\mathrm{EF}=47 \%$ after it was implemented); the same was true for respiratory organs diseases $(\mathrm{EF}=51 \%$ prior to the program implementation; $\mathrm{EF}=39 \%$ after it was implemented). A number of workers in the test group who had high BP at the moment the examination took places decreased authentically (33\% prior to the program implementation; $11 \%$ after it was implemented, $p<0.05, \mathrm{RR}=1.1 ; 95 \% \mathrm{CI}=1.0-3.3 ; \mathrm{EF}=$
$39 \%$ ); there was a 1.8 time decrease in number of workers who had contraindications to fulfilling certain work tasks as per PME results due to CSD (14 workers prior to the program implementation, and 8 workers after it was implemented, $p<0.05$ ); and number of workers with such contraindications due to ROD went down by 3 times (32 workers prior to the program implementation, and 11 workers after it was implemented, $p<0.05$ ); a number of workers who applied for medical aid due to CSD and ROD including acute respiratory infections when down by 2.5 times; there was a decrease in number of workers who needed additional examinations (from $35 \%$ to $20 \%$ ) and whose occupational abilities were to be estimated (from $30 \%$ to $14 \%$ ); there was practically a 3-time decrease in number of workers who couldn't continue their work due to contraindications (from $33 \%$ to $11 \%$ due to $\mathrm{AH}$, and from $14.5 \%$ to $5 \%$ due to respiratory organs diseases). There was a positive dynamics revealed via comparative analysis of the examination results (Table 5).

We analyzed functional activity of the brachial artery endothelium and revealed that prior to the program implementation minimal growth in diameter amounted to $5 \%$, and maximum one, to $32 \%$, variation range $\mathrm{R}=27$; after the program was implemented, the parameters became equal to $10.42 \%$ and $28.57 \%$ accordingly, $\mathrm{R}=18.15 \%$ (Table 6 ).

Table 5

Comparative analysis of laboratory parameters prior to the program implementation and after it

\begin{tabular}{|l|c|c|c|}
\hline \multicolumn{1}{|c|}{ Parameters } & $\begin{array}{c}\text { Prior to the program } \\
\text { implementation }\end{array}$ & $\begin{array}{c}\text { After the program } \\
\text { was implemented }\end{array}$ & $p^{*}$ \\
\hline Low density lipoproteins, $\mathrm{mmol} / \mathrm{dm}^{3}$ & $5.5 \pm 0.5$ & $4.9 \pm 0.2$ & $<\mathbf{0 . 0 5}$ \\
\hline C-reactive protein, supersensitive, $\mathrm{mg} / \mathrm{dm}^{3}$ & $6.7 \pm 2.2$ & $4.7 \pm 0.5$ & $<\mathbf{0 . 0 5}$ \\
\hline Uric acid, $\mu \mathrm{mol} / \mathrm{dm}^{3}$ & $390 \pm 82.7$ & $267 \pm 37.3$ & $<\mathbf{0 . 0 5}$ \\
\hline Homocysteine, $\mathrm{mg} / \mathrm{dm}^{3}$ & $15.1 \pm 3.2$ & $8.9 \pm 2.4$ & $<\mathbf{0 . 0 5}$ \\
\hline
\end{tabular}

$\mathrm{N}$ o t e : * $p$ means validity of discrepancies between groups.

Table 6

Functional activity of the brachial artery endothelium: comparative analysis prior to and after the program implementation

\begin{tabular}{|l|c|c|c|}
\hline \multicolumn{1}{|c|}{ Parameter } & $\begin{array}{c}\text { Prior to the program } \\
\text { implementation }\end{array}$ & $\begin{array}{c}\text { After the program } \\
\text { was implemented }\end{array}$ & $p^{*}$ \\
\hline Minimal growth in the brachial artery diameter, \% & 5 & 10.42 & $<\mathbf{0 . 0 5}$ \\
\hline Maximum growth in the brachial artery diameter, \% & 32 & 28.57 & $<\mathbf{0 . 0 5}$ \\
\hline $\begin{array}{l}\text { Variation range (a difference between minimal and } \\
\text { maximum growth in diameter, \%) }\end{array}$ & 27 & 18.15 & $<\mathbf{0 . 0 5}$ \\
\hline
\end{tabular}

$\mathrm{N}$ o t e : ${ }^{*} p$ means validity of discrepancies between the test and the reference groups. 
Table 7

Ultrasound scanning performed on brachiocephalic arteries: comparative analysis of the results prior to and after the program implementation

\begin{tabular}{|c|c|c|c|}
\hline Parameter & Prior to the program implementation & After the program was implemented & $p^{*}$ \\
\hline Intima-media thickness & $1.2 \pm 0.09$ & $0.9 \pm 0.07$ & $<\mathbf{0 . 0 5}$ \\
\hline
\end{tabular}

$\mathrm{N}$ o t e : ${ }^{*} p$ means validity of discrepancies between the test and the reference groups.

Ultrasound scanning performed on BCA prior to the program implementation and after it revealed a decrease in IMT and it also indicated that there was an improvement in vessel endothelium structure (Table 7).

We assessed efficiency of prevention program implementation and revealed that a relation between atherogenic cholesterol fractions (LDLP) and working conditions ceased to be authentic $(\mathrm{RR}=1.2,95 \% \mathrm{CI}=0.9-1.6)$; and there was a decrease in etiological fraction and relative risks for such parameters as contents of uric acid in blood $(\mathrm{RR}=1.3,95 \% \mathrm{CI}=1.3-9.6$; $\mathrm{EF}=32.5 \%)$ and functional activity of the brachial artery endothelium $(\mathrm{RR}=2.1,95 \%$ $\mathrm{CI}=1.1-6.3 ; \mathrm{EF}=33 \%$; that is, there was a reduction in risks of circulatory system diseases and respiratory organs diseases

\section{Conclusions.}

1. When the corporate prevention program was implemented, it resulted in lower occupational causality of certain diseases for workers employed at chemical production; it was true for circulatory system diseases $(\mathrm{EF}=66 \%$ prior to the program implementation; $\mathrm{EF}=47 \%$ after it was implemented) and respiratory organs diseases $(\mathrm{EF}=51 \%$ prior to the program implementation; $\mathrm{EF}=39 \%$ after it was implemented).

2. The prevention program implementation led to practically a 3-time decrease in number of workers who couldn't continue their work due to contraindications (from $33 \%$ to $11 \%$ due to $\mathrm{AH}$, and from $14.5 \%$ to $5 \%$ due to respiratory organs diseases).

3. Implementation of corporate prevention programs at enterprises allows reducing risks of circulatory system diseases and respiratory origins diseases, gives a worker an opportunity to preserve his or her working ability, and helps an employer preserve labor potential of an enterprise.

Funding. The research was not granted any sponsor support.

Conflict of interests. The authors declare there is no any conflict of interests.

\section{References}

1. Maslennikova G.Ya., Oganov R.G. Prevention of noncommunicable diseases as an opportunity to increase life expectancy and healthy longevity. Kardiovaskulyarnaya terapiya i profilaktika, 2019, no. 2, pp. 5-12 (in Russian).

2. Romeiko V.L., Poteryaeva E.L., Ivleva G.P., Kruglikova N.V., Trufanova N.L. The main problems concerning improvement for legal mechanisms of maintaining professional health of the working population. Zdorov'e naseleniya i sreda obitaniya, 2018, vol. 307, no. 10, pp. 46-49 (in Russian).

3. Valeeva E.T., Bakirov A.B., Kaptsov V.A., Karimova L.K., Gimaeva Z.F., Galimova R.R. Occupational risks for health of the workers of the chemical complex. Health Risk Analysis. 2016, no. 3, pp. 88-97. DOI: $10.21668 /$ health.risk/2016.3.10.eng

4. Titova E.Ya., Golub' S.A. Contemporary problems of health protection for workers employed at a large industrial enterprise and working under occupational hazards. Health Risk Analysis, 2017, no. 4, pp. 83-90. DOI: 10.21668/health.risk/2017.4.09.eng

5. Alekseev V.B., Shur P.Z., Shlyapnikov D.M., Kostarev V.G. Hygienic evaluation of the impact of working conditions on the health of workers of the complex for production of phthalic anhydride and fumaric acid. Gigiena $i$ sanitariya, 2018, vol. 97, no. 1, pp. 54-58 (in Russian).

6. Panev N.I., Korotenko O.Yu., Filimonov S.N., Semenova E.A., Panev R.N. Prevalence of cardiovascular pathology in workers of the aluminum industry Gigiena $i$ sanitariya, 2019, vol. 98, no. 3, pp. 276-279 (in Russian).

7. Ponomareva T.A., Vlasova E.M., Shklyaev O.V. Prevalence, etiological factors and structure of occupational bronchial asthma in diverse industrial sectors of the republic of Bashkortostan. Meditsina truda $i$ ekologiya cheloveka, 2017, vol. 11, no. 3, pp. 43-48 (in Russian).

8. Bazarova E.L., Fedoruk A.A., Roslaya N.A., Osherov I.S., Babenko A.G. Experience of workplace hazard assessment connected with effect of the cooling microclimate in the conditions of modernization of the enterprise. Zdorov'e naseleniya i sreda obitaniya, 2019, vol. 318, no. 9, pp. 56-61 (in Russian). 
9. Denisov E.I., Stepanyan I.V., Chelishcheva M.Yu. Statisticheskaya otsenka svyazi narushenii zdorov'ya s rabotoi (SOS) [Statistic assessment of a relation between health disorders and work (SAR)]. Neirokibernetika. Available at: http://neurocomp.ru/cgi-bin/opr/sos/start.py (06.04.2020) (in Russian).

10. Boiko I.V., Andreenko O.N., Greben'kov S.V., Shalukho E.S., Fedorov V.N., Orlova G.P. The experience of joint work of the clinic of occupational pathology (center of occupational pathology) and the department of the scientific support of sanitary and epidemiological surveillance and expertise to establish the connection of diseases with the occupation. Gigiena i sanitariya, 2018, vol. 97, no. 12, pp. 1239-1243 (in Russian).

11. Meshchakova N.M., Shayakhmetov S.F., D'yakovich M.P. The improvement of methodical approaches to the health risk assessment in workers exposed to the chemical factor. Gigiena $i$ sanitariya, 2017, vol. 96, no. 3, pp. 270-274 (in Russian).

12. Zaitseva N.V., Shur P.Z., Kir'yanov D.A., Chigvintsev V.M., Dolgikh O.V., Luzhetskii K.P. Methodical approaches to calculating the probability of negative responses for personal human health risk assessment. Profilakticheskaya i klinicheskaya meditsina, 2015, vol. 56, no. 3, pp. 5-11 (in Russian).

13. Shushkova T.S., Tulakin A.V., Ustyushin B.V., Suchalkin B.N., Kutakova N.S., Shubenkova T.I. Metodicheskie podkhody $\mathrm{k}$ integral'noi otsenke funktsional'nogo sostoyaniya organizma gornorabochikh [Methodical approaches to integral assessment of miners' functional state]. Sanitarnyi vrach, 2013, no. 4, pp. 40-45 (in Russian).

14. Lebedeva-Nesevrya N.A., Barg A.O., Tsinker M.Yu., Kostarev V.G. Assessment of correlation between heterogeneous risk factors and morbidity among working population in Russian regions with different background of health formation. Health Risk Analysis, 2019, no. 2, pp. 91-100. DOI: 10.21668/health.risk/2019.2.10.eng

15. Zaitseva N.V., Shur P.Z., Kir'yanov D.A., Kamaltdinov M.R., Tsinker M.Yu. Methodical approaches for health population risk estimation based evolution models. Zdorov'e naseleniya $i$ sreda obitaniya, 2013, no. 1, pp. 4-6 (in Russian).

16. Chigvintsev V.M. Analiz matematicheskoi modeli regulyatsii raboty immunnoi i neiroendokrinnoi sistem s uchetom funktsional'nykh narushenii organov [Analysis of a mathematical model that describes immune and endocrine systems regulation taking into account functional disorders in organs]. Matematicheskoe modelirovanie v estestvennykh naukakh, 2017, no. 1, pp. 128-131 (in Russian).

17. Pryanichnikova N.I., Mazhaeva T.V., Dubenko S.E., Obukhova T.Yu., Chirkova I.A. Risk factors and metabolic disorders possibility in workers at an enterprise included into «Uralasbest» public corporation. Meditsina truda i promyshlennaya ekologiya, 2014, no. 6, pp. 22-25 (in Russian).

18. Strakhova L.A., Blinova T.V., Troshin V.V., Kolesov S.A., Rakhmanov R.S., Umnyagina I.A. The evaluation of oxidative stress as a criterion of the risk of disease development in working people of various ages. Meditsina truda i ekologiya cheloveka, 2018, no. 2, pp. 61-65 (in Russian).

19. Baradaran A., Nasri H., Rafieian-Kopaei M. Oxidative stress and hypertension: Possibility of hypertension therapy with antioxidants. Journal of Research in Medical Sciences: The Official Journal of Isfahan University of Medical Sciences, 2014, vol. 19, no. 4, pp. 358-367.

20. Bernatova I. Endothelial dysfunction in experimental models of arterial hypertension: cause or consequence? BioMed research international, 2014, 598271 p. Available at: http://www.hindawi.com/journals/bmri/2014/598271 (05.09.2019).

21. Golbidi S., Frisbee J.C., Laher I. Chronic stress impacts the cardiovascular system: animal models and clinical outcomes. American journal of physiology. Heart and circulatory physiology, 2015, vol. 308, no. 12, pp. 1476-1498. DOI: 10.1152/ajpheart.00859.2014

22. Jiménez M.C., Rexrode K.M., Glynn R.J., Ridker P.M., Gaziano J.M., Sesso H.D. Association between High-Sensitivity C-Reactive Protein and Total Stroke by Hypertensive Status Among Men. Journal of the American Heart Association, 2015, vol. 9, no. 4, pp. e002073. DOI: 10.1161/JAHA.115.002073

23. Bushueva T.V., Roslaya N.A., Roslyi O.F. Comparative analysis of the immune profile of metallurgical workers exposed to different chemical factors of production environment. Gigiena i sanitariya, 2015, vol. 94, no. 2, pp. 47-50 (in Russian).

Ustinova O.Yu., Zaitseva N.V., Vlasova E.M., Kostarev V.G. Corporate programs for preventing health disorders among workers employed at adverse productions as a tool for occupational risk management. Health Risk Analysis, 2020, no. 2, pp. 72-82. DOI: 10.21668/health.risk/2020.2.08.eng

Received: 23.04.2020

Accepted: 03.06.2020

Published: 30.06 .2020 